\title{
FAKTOR YANG BERHUBUNGAN DENGAN DEPRESI PADA PASIEN PENYAKIT PARKINSON DI KOTA PADANG
}

\author{
Reno Bestari ${ }^{1)}$, Yuliarni Syafrita ${ }^{2)}$ \\ ${ }^{1}$ Fakultas Kedokteran, Universitas Andalas, Jl.Perintis Kemerdek aan No. 14 D, Sawahan Timur, Padang. \\ email: bestari.reno@gmail.com \\ ${ }^{2}$ Fakultas Kedokteran, Universitas Andalas, Jl. Perintis Kemerdekaan No. 14 D, Sawahan Timur, Padang. \\ email:ysyafrita@yahoo.com
}

Submitted: 13-0w-2020, Reviewer: 20-02-2020, Accepted: 21-02-2020

\begin{abstract}
Abstrak
Depresi merupakan gejala non-motor terbanyak pada pasien Parkinson yang sangat mempengaruhi kualitas hidup, namun pada praktek klinis sering terabaikan. Tujuan penelitian ini adalah untuk melihat angka kejadian depresi dan faktor apa saja yang berhubungan dengan depresi pada pasien penyakit Parkinson dengan menggunakan Montgomery Asberg Depression Rating Scale (MADRS). Desain penelitian adalah cross sectional. Penelitian dilakukan pada pasien penyakit Parkinson yang berobat ke Poliklinik RS Dr. M. Djamil dan beberapa rumah sakit di Kota Padang. Didapatkan 62 pasien penyakit Parkinson (56,5\% laki-laki) dengan rentang usia 35-78 tahun. Berdasarkan kuisioner MADRS didapatkan 34 pasien $(54,8 \%)$ mengalami depresi, dimana 24 pasien depresi ringan $(71 \%)$ dan 10 pasien depresi sedang (29\%). Depresi pada pasien penyakit Parkinson cukup tinggi, dimana lebih setengah dari pasien penyakit Parkinson dalam penelitian ini mengalami depresi.
\end{abstract}

Kata kunci: penyakit Parkinson, depresi, Montgomery Asberg Depression Rating Scale.

\begin{abstract}
Depression is a non-motor symptom in Parkinson's patients which greatly affects quality of life, but in clinical practice it is often overlooked. The purpose of this study was to preview the depression using the Montgomery Asberg Depression Rating Scale (MADRS) and what factors are associated with depression in Parkinson's disease. In this cross sectional study, total subject were 62 patients with Parkinson's disease in outpatient care in some hospitals in Padang. There were 56.5\% male with an age range was 35-78 years. Based on the MADRS questionnaire obtained 34 patients (54.8\%) have depression, 24 (71\%) patients with mild depression and $10(29 \%)$ patients with moderate depression. The patients with depression were more than without depression in Parkinson's disease.
\end{abstract}

Keywords: Parkinson's disease, depression, Montgomery Asberg Depression Rating Scale.

\section{PENDAHULUAN}

Parkinson's disease (PD) merupakan penyakit neurodegeneratif kronik kedua terbanyak dengan prevalensi sedikit dibawah Alzheimer's disease (Ketharanathan, et al, 2014). Jumlah penderita PD saat ini 1-2 per 1000 orang dengan prevalensi yang terus meningkat seiring dengan pertambahan umur, yaitu sekitar $1 \%$ pada populasi diatas 60 tahun (Tysnes O, et al, 2017).
Depresi merupakan gejala non-motor terbanyak pada PD, yaitu $\pm 40 \%$ dari semua pasien PD dan insidennya meningkat $1,86 \%$ pertahun (Santiago RM, et al, 2016). Penelitian yang dilakukan pada fase motor awal (kurang dari 5 tahun setelah terdiagnosis) menunjukkan adanya hubungan antara kerusakan sistem monoaminergik dan gangguan emosional. Perubahan pada sirkuit neural berhubungan dengan kontrol emosi dapat menjadi marker 
yang sensitif terhadap proses neurodegeneratif yang terus berlangsung, sehingga dapat memfasilitasi untuk mendiagnosis lebih dini pada fase awal (Borgonovo J, 2016).

Depresi pada PD dapat mempercepat perburukan gangguan motorik/disabilitas dan juga meningkatkan mortalitas. Sebuah survey dengan jumlah pasien yang cukup banyak memperlihatkan dampak gangguan neuropsikiatri yang lebih besar terjadi pada stadium awal PD, hal ini membuktikan bahwa gangguan neuropsikiatri seperti depresi dan anxietas bukan merupakan reaksi dari stress akibat keterbatasan kemampuan yang dialami pasien, tapi akibat perubahan proses neuropatologis (Menon B, et al, 2015).

Depresi pada pasien PD kadang tidak terdiagnosis dan juga tidak diobati. Aspek kualitas hidup mulai ditekankan dalam diagnosis dan pengobatan sebagai respon kriteria untuk terapi (Lemke MR, 2008).

\section{METODE PENELITIAN}

Penelitian dilakukan terhadap pasien PD yang berobat ke RS Dr. M. Djamil dan beberapa RS di kota Padang. Desain penelitian adalah cross sectional. Pasien dikumpulkan secara konsekutif dari Juni 2019 sampai Februari 2020. Pasien yang dimasukkan dalam penelitian sebelumnya sudah didiagnosis sebagai Parkinson's disease oleh spesialis Neurologi. Kriteria eksklusi antara lain riwayat stroke, Parkinson sekunder dan sindroma Parkinson, pasien yang tidak dapat berkomunikasi, dan yang telah mendapat terapi antidepresi. Kemudian dilakukan tanya jawab kepada pasien dan keluarga berdasarkan Montgomery Asberg Depression Rating Scale (MADRS).

Awalnya dilakukan pencatatan data karakteristik demografi dan klinis pasien seperti umur, jenis kelamin, pendidikan, usia saat onset, status pernikahan, dan durasi penyakit. Kemudian juga dilakukan penilaian terhadap derajat penyakit Parkinson dengan menggunakan kriteria Hoehn \& Yahr. Setelah itu dilakukan penilaian derajat depresi dengan menggunakan MADRS.

Analisa statistik dilakukan secara komputerisasi dengan SPSS 25.0. Variabel kontinu disajikan sebagai mean \pm standard deviation (SD) dan hubungan antar variabel dianalisis menggunakan uji $\mathrm{T}$ tidak berpasangan dan Mann-Whithney U. Nilai $p<0,05$ dianggap bermakna secara statistik.

\section{HASIL DAN PEMBAHASAN}

Pada penelitian ini didapatkan 62 orang pasien PD yang berobat ke Poliklinik RS Dr. M. Djamil dan beberapa RS di kota Padang. Dalam penelitian ini didapatkan sebanyak 34 orang $(54,8 \%)$ mengalami depresi, 24 orang diantaranya mengalami depresi ringan dan 10 orang dengan depresi sedang. Hasil ini sedikit lebih tinggi dari data yang ditampilkan oleh Reijnders yang menyebutkan bahwa depresi merupakan gangguan neuropsikiatri yang paling sering ditemui pada pasien Parkinson, yakni 4050\% pasien (Weintraub D, et al, 2007).

Rerata usia pasien saat penelitian ini 65 tahun dengan rentang usia 35-78 tahun. Usia saat onset penyakit Parkinson 58,05 \pm 9,97 tahun. Rerata pasien menderita Parkinson adalah 5 tahun dengan rentang 125 tahun. Rerata usia saat onset yang didapatkan pada penelitian ini sedikit lebih rendah dibandingkan penelitian Pagano et al yang dilakukan pada tahun 2014, dimana dari 422 pasien Parkinson didapatkan usia saat onset $61,6 \pm 9,73$ tahun, dan juga ditemukan beberapa pasien dengan usia saat onset $<50$ tahun (Pagano, 2016).

Subjek penelitian didominasi pasien dengan tingkat pendidikan yang tinggi, dimana hanya $32 \%$ dengan tingkat pendidikan rendah. Tingkat pendidikan dibagi menjadi 2 kelompok, hal ini sejalan 
dengan penelitian Gusstafsson pada tahun 2005 di Swedia, Pendidikan dibagi menjadi 2 kelompok, rendah (sekolah $\leq 9$ tahun) dan tinggi ( $>9$ tahun) (Gusstafsson, 2015).

Subjek penelitian dengan status menikah sebanyak 44 orang (71\%). Hoehn and Yahr merupakan kriteria untuk menilai derajat keparahan pasien Parkinson dan dalam penelitian ini sebagian besar berada pada stadium III dan hanya 2 subjek dengan Hoehn and Yahr V. Dimana derajat Hoehn and Yahr yang tinggi dapat menjadi faktor risiko terjadinya depresi pada Parkinson (Custodio N, et al, 2018). Data karakteristik dasar disajikan dalam tabel 1.

Tabel 1. Karakteristik dasar pasien

\begin{tabular}{|c|c|}
\hline Karakteristik das ar, $n=62$ & Frekuensi \\
\hline Depresi, $n(\%)$ & $34(54,8)$ \\
\hline Ringan & $24(71)$ \\
\hline Sedang & $10(29)$ \\
\hline \multicolumn{2}{|l|}{ Usia (tahun) } \\
\hline Median & $65(35-78)$ \\
\hline \multicolumn{2}{|l|}{ Jenis Kelamin, n (\%) } \\
\hline Laki-laki & $35(56,5)$ \\
\hline Perempuan & $27(43,5)$ \\
\hline \multicolumn{2}{|l|}{ Usia saat onset (tahun) } \\
\hline Mean \pm SD & $58,05 \pm 9,97$ \\
\hline \multicolumn{2}{|l|}{ Durasi Sakit (tahun) } \\
\hline Median & $5(1-25)$ \\
\hline \multicolumn{2}{|l|}{ Tingkat Pendidikan, $\mathrm{n}(\%)$} \\
\hline Rendah & $20(32,3)$ \\
\hline Tinggi & $42(67,6)$ \\
\hline \multicolumn{2}{|l|}{ Status Perkawinan, $\mathrm{n}(\%)$} \\
\hline Kawin & $44(71)$ \\
\hline Tidak kawin & $18(29)$ \\
\hline \multicolumn{2}{|l|}{ Hoehn and Yahr, n (\%) } \\
\hline I & $9(14,5)$ \\
\hline II & $14(22,6)$ \\
\hline III & $28(45,2)$ \\
\hline IV & $9(14,5)$ \\
\hline $\mathrm{V}$ & $2(3,2)$ \\
\hline
\end{tabular}

Tabel 2 memperlihatkan hubungan antara faktor-faktor yang mempengaruhi depresi pada penyakit Parkinson, nilai $\mathrm{p}<0,05$ dianggap berhubungan bermakna. Untuk median usia antara kedua kelompok tampak tidak jauh berbeda, sehingga tidak terdapat hubungan yang bermakna antara usia dengan depresi, dimana didapatkan nilai $\mathrm{p}=0,859$. 
Untuk jenis kelamin, didapatkan jumlah pasien laki-laki lebih banyak, baik pada kelompok dengan depresi maupun kelompok tanpa depresi. Akan tetapi jenis kelamin tidak berhubungan bermakna dengan kejadian depresi. Tingkat pendidikan juga tidak berhubungan dengan depresi pada penyakit Parkinson, dengan nilai $\mathrm{p}=0,267$. Begitu juga dengan status perkawinan, tidak didapatkan hubungan yang bermakna antara 2 kelompok.

Didapatkan hubungan yang bermakna antara durasi menderita Parkinson dengan kejadian depresi. Tampak rerata durasi sakit kelompok dengan depresi lebih lama dibandingkan kelompok tanpa depresi, nilai $\mathrm{p}=0,008$.

Tabel 2. Hubungan faktor yang mempengaruhi depresi pada penyakit Parkinson

\begin{tabular}{|c|c|c|c|}
\hline \multirow{2}{*}{ Variabel } & \multicolumn{2}{|c|}{ Parkinson } & \multirow{2}{*}{$\mathbf{p}$} \\
\hline & Depresi & Tanpa depresi & \\
\hline \multicolumn{4}{|l|}{ Usia (tahun) } \\
\hline Median & $64(35-78)$ & $65(49-77)$ & 0,859 \\
\hline \multicolumn{4}{|l|}{ Jenis Kelamin, $\mathrm{n}(\%)$} \\
\hline Laki-laki & $19(55,9)$ & $16(57,1)$ & 0.921 \\
\hline Perempuan & $15(44,1)$ & $12(42,9)$ & \\
\hline \multicolumn{4}{|c|}{ Tingkat pendidikan, $\mathrm{n}(\%)$} \\
\hline Rendah & $13(38,2)$ & $7(25)$ & 0,267 \\
\hline Tinggi & $21(61,8)$ & $21(75)$ & \\
\hline \multicolumn{4}{|c|}{ Status perkawinan, $\mathrm{n}(\%)$} \\
\hline Kawin & $23(67,6)$ & $21(75)$ & 0,526 \\
\hline Tidak kawin & $11(32,4)$ & $7(25)$ & \\
\hline \multicolumn{4}{|l|}{ Durasi sakit (tahun) } \\
\hline Mean \pm SD & $7,29 \pm 4,84$ & $5,36 \pm 5,6$ & 0,008 \\
\hline \multicolumn{4}{|l|}{ Hoehn and Yahr } \\
\hline Median & $3(1-5)$ & $2(1-3)$ & 0,000 \\
\hline
\end{tabular}

Derajat Hoehn and Yahr juga memiliki hubungan yang bermakna dengan kejadian depresi pada pasien Parkinson. Dimana semakin tinggi derajat Hoehn and Yahr pasien, maka akan meningkatkan risiko pasien mengalami depresi.

\section{SIMPULAN}

Depresi merupakan gejala non-motor pada penyakit Parkinson. Namun, gejala ini kadang kurang mendapat perhatian karena pasien, keluarga ataupun dokter lebih fokus pada gejala motorik yang timbul. Perlu skrining dan penatalaksanaan yang tepat dalam menghadapi depresi pada pasien Parkinson, karena depresi semakin menurunkan kualitas hidup pasien Parkinson. Dari penelitian ini, didapatkan hubungan yang bermakna antara lama sakit dan derajat Hoehn and Yahr pasien dengan kejadian depresi pada Parkinson.

\section{REFERENSI}

Borgonovo J, Allende-Castro C, Laliena A, Guerrero N, Silva H, Concha M. 2016. Change in neural circuitry associated with depression at pre-clinical, pre-motor and 
early motor phases of Parkinson's disease. $1-8$.

Custodio N, Diaz C, Mariños C, Mejía-Rojas K, Lira D, Montesinos R. 2018.Factors associated with depression in patients with Parkinson's disease A multicenter study in Lima, Peru. Dement Neuropsychology; 12(3):292-298.

Ketharanathan T, Hanwella R, Weerasundera R, Silva V. 2014. Major depressive disorder in Parkinson's disease : a cross-sectional study in Sri Lanka. Biomed central Psychiatry, 14: 278-285.

Lemke MR. 2008. Depressive symptoms in Parkinson's disease.European Journal of Neurology, 15 (Suppl. 1):21-25.

Menon B, Nayar R, Kumar S , Cherkil S, Venkatachalam A, Surendran K, Deepak S. 2015. Parkinson's Disease, Depression, and Quality-of-Life. Indian Journal of Psychological medicine. Apr - Jun 2015, Vol 37 Issue 2 ; 144-149.

Pagano G, Ferrara N, Brooks D, Pavese N. 2016 Age at onset and Parkinson disease phenotype, American Academy of Neurology;86(15):1400-1407.

Santiago RM, Vital M, Sato M, Adam G. 2016. Depression in Parkinson's Disease is Associated with a Serotoninergic System Change Secondary to Neuroinflammation. International Journal Neurology Neurotherapy, 3:1-4.

Tysnes O, Storstein A. 2017. Epidemiology of Parkinson's disease. Journal of neural transmission 124(8) : 901-905.

Weintraub D, Stern M. 2007. Handbook of clinical neurology : disorder of mood and affect in Parkinson's disease, vol 83 ; 421 430.
Gusstafsson H, Nordtrom A, Nordstrom P. 2015. Depression and subsequent risk of Parkinson disease:A nationwide cohort study. American Academy of Neurology84(24): 2422-2429. 